\title{
Assessing the Effect of Dome Shape and Location on The Acoustical Performance of a Mosque by Using Computer Simulation
}

\author{
N. Che Din ${ }^{1,2, *}$ and A. S. Anuar ${ }^{2}$ \\ ${ }^{1}$ The Centre for Building, Construction \& Tropical Architecture (BuCTA), Faculty of \\ Built Environment, University of Malaya, 50603, Kuala Lumpur, Malaysia. \\ ${ }^{2}$ Department of Architecture, Faculty of Built Environment, University of Malaya, \\ 50603 Kuala Lumpur, Malaysia. \\ *Email: nazlichedin@um.edu.my
}

\begin{abstract}
Architecturally, the dome is one evolutionary presence in most mosques of modern day. Besides mihrab, the dome is one of the architectural elements that has a phenomenon of concentration of energy by reflected sound waves from concave surfaces. The aim of this research is to compare the acoustical performance of different shapes of the dome and their respective locations by using geometrical approach computer simulation. Four types of dome that are commonly used on a mosque; Arabic, segmental, hemispherical, and onion, were modeled to compare their acoustical parameters i.e. reverberation time (RT) and speech transmission index (STI). It can be concluded that the shape of the dome does affect the RT. Furthermore, the shape of the dome also affects the STI - the larger the volume, the lower the STI value. However, the locations of a dome have little significance over acoustical parameter. The findings of this research may not limit to mosques only, but to any similar building that has similar typology.
\end{abstract}

Keywords: Mosque; dome shape; reverberation time; speech transmission index; ODEON.

\section{INTRODUCTION}

Mosque or masjid in Arabic is a place of worship where Muslims come to do their congregational prayer since the formation of Islam in $622 \mathrm{CE}$. Besides being a place of worship, a mosque is also considered a public space used by Muslims for activities such as daily praying, Quran recitation, and Friday prayer and its lecture [1-4]. These activities involve a lot of speeches, so the praying hall needs to be acoustically satisfactory and comfortable. Other functions of a mosque includes being a madrasah(a religious school and a small library), a discussion space, a soup kitchen to feed the poor, and a medical facility [5-7].

Nowadays, instead of focusing on the element of the mosque, materials study and the use of sound reinforcement system are most popular solutions to counter basic problems in acoustical comforts in a space i.e. main prayer hall. Acoustics prediction can save time, cost, energy and resources [8-11], especially when the prediction work takes place during the early stages of the design work [12]. The ability of predicting building performance is a potent instrument in the construction industry.

With the aid of computer technology, 3-dimensional (3D) modelling and geometrical acoustics simulation techniques have been widely used due to demanding development over the past decade [13-16]. Besides having the advantages of viewing the 
space in a $3 \mathrm{D}$ viewpoint, these modelling tools can also be used as a powerful medium to explore architecturally the design ideas, forms, shapes, spaces and function [17-19].

Architectural styles in mosques is also influenced or learned from foreigners and by settlers moving to the specific settlement. The earlier mosques i.e. traditional vernacular architectural styles, were generally constructed with pyramidal roof to respond to regional climate. Later mosques reflect influences of external architectural styles, in particularly the dome [20]. Architecturally, it is easy to identify a mosque in this era - the changes to its appearances since the birth of its existence are very minor. Mosques also come in all shapes and sizes, varying from region to region albeit having similar features such as dome, minaret and mihrab [21]. Identifying a mosque exterior architecturally is when there is a presence of tall minarets and a large dome; in particular regions, only minarets are present, functioning to call a congregation to prayers, being highly visible from afar [22]. Nowadays, the dome has become one of the symbols to identify a mosque.

Recently, the dome not only structurally sits on top of a flat roof, but it is mostly part of the structure of the roof itself. The structure or architectural elements of a dome has the spatial arrangement to reflect sound waves and create echoes [23]. A dome's material properties and capabilities are also essential to give impact towards acoustical performance and should take into consideration in early design stages. A dome can also create an effect called the "whispering gallery" and normally happens below a dome or a vault [24]. This theory has been proven at The Salle de Cariatides in the Louvre, Paris, France, Basilica of St. John Lateran, Rome and St Paul's Cathedral in London where a whispering gallery was first discovered [25]. The reverberation time in the places with big volumes and has low absorbent surfaces will normally have long reverberation time resulted to reduce speech intelligibility performance. In addition, the walls and vaults or ceiling may contribute to longer reverberation time because these elements usually have quality reflectors [26].

Furthermore, the speech intelligibility in a mosque is potentially being hampered by the reverberation time and/or echoes due to a presence of a large size of volume in a traditional mosque, and by sheltering elements that are mostly either domed or vaulted. The dome also reduces the effect of sound focusing due to it dropping the global reverberation time within the main prayer hall [27]. In this research, the main objective is to evaluate the acoustical performance i.e. reverberation time (RT) and speech transmission index (STI) of different types of dome shape and their respective locations by using geometrical approach computer simulation.

\section{EXPERIMENTAL SET UP}

\section{Design of Experiment}

Google Sketchup ${ }^{\circledR}$ was used to design all the respective room models. The praying hall size of $30 \mathrm{~m}$ width $\times 30 \mathrm{~m}$ length with a height of $6 \mathrm{~m}$ was created as a base model. Dome heights were varied but all models share the maximum height of $10 \mathrm{~m}$ from the ground.

Dome comes with a variety of shapes due to different era, cultural and construction wise. The few types of dome are Corbel dome [28], cloister vault [29] compound dome or pendentive dome [30], oval domes [31], saucer dome [29]. Saucer dome is also called segmental dome which sometimes is used for cloister vaults or calottes because it has a lower profile and is less than a hemisphere. The dome types that will be modeled and simulated in this research are the Arabic, segmental, hemispherical and 
onion dome shapes as depicted in Table 1. These shapes have been chosen because they are commonly used for mosques in Malaysia.

Table 1. The description of room model with different types of dome.

\begin{tabular}{|c|c|c|}
\hline Dome type & Model & Volume $\left(\mathrm{m}^{3}\right)$ \\
\hline No Dome & & 5400.00 \\
\hline Arabic & & 6616.60 \\
\hline Segmental & & 5748.25 \\
\hline Hemispherical & & 6345.98 \\
\hline Onion & & 6927.44 \\
\hline
\end{tabular}

The size of the dome regardless of the type were maintained at $15 \mathrm{~m}$ diameter and was located at the centre of the praying hall. Then, the additional models were created and installed at different locations as shown in Figure 1, which were the front area and the back area of the praying hall.

\section{Experimental Procedure}

All room models were created using Google Sketchup ${ }^{\circledR}$, and were then exported into ODEON Room Acoustic Software 13.0 [32]. When assigning a new room in ODEON, 
its validity was verified. The verification involved water tightness test to determine whether the room model was completely enclosed in order to ensure the accuracy of simulation. The materials assigned to this simulation are as shown in Table 2.

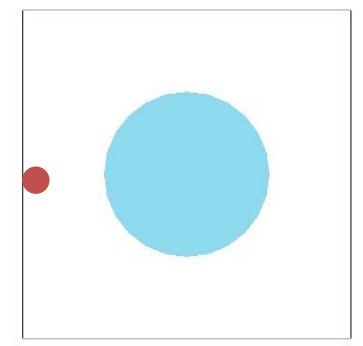

(a) Center

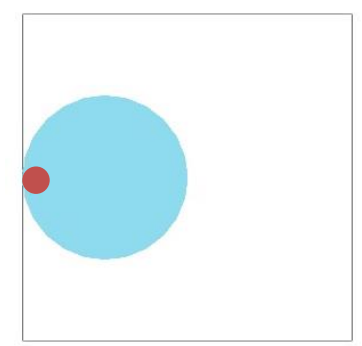

(b) Front

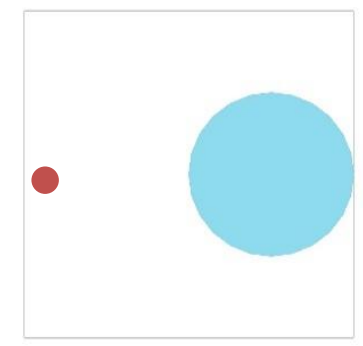

(c) Back

Figure 1: Location of dome ( $\bullet$ Sound source).

Table 2: The materials used and with its absorption coefficiency.

\begin{tabular}{llllll}
\hline \multirow{2}{*}{ Architectural Elements } & \multicolumn{1}{c}{ Material } & \multicolumn{4}{c}{ Absorption Coefficient } \\
\cline { 3 - 6 } & \multicolumn{4}{c}{ Frequency (Hz) } \\
\cline { 2 - 6 } Floor & $\begin{array}{l}\text { Carpet heavy, on concrete } \\
\text { (Harris, 1991) }\end{array}$ & 0.06 & 0.14 & 0.37 & 0.6 \\
\hline Walls & $\begin{array}{l}\text { Smooth brickwork, 10mm } \\
\text { dep pointing, pit sand } \\
\text { mortar (Kristensen, 1984) }\end{array}$ & 0.09 & 0.12 & 0.16 & 0.22 \\
\hline Ceiling \& Inner dome surface & $\begin{array}{l}\text { Smooth brickwork, 10mm } \\
\text { dep pointing, pit sand } \\
\text { mortar (Kristensen, 1984) }\end{array}$ & 0.09 & 0.12 & 0.16 & 0.22 \\
\hline Sliding door \& window & $\begin{array}{l}\text { Glass, Ordinary window } \\
\text { Glass (Harris) }\end{array}$ & 0.25 & 0.18 & 0.12 & 0.07 \\
\hline
\end{tabular}

This simulation was to identify the effectiveness of the shapes and their locations, so that the materials assigned to them in this study were not identical to any existing mosques, and to be used similarly with all the other models. Sound source and receivers were defined orderly. Single points of natural raised sounds as shown in Figure 2 and Table 3 were used as the sound source. The sound source was placed $1.5 \mathrm{~m}$ set back from the edge of qibla wall and raised $1.3 \mathrm{~m}$ from the floor. The positioning of a single sound source was arranged based on the typical Imam's (the person who leads prayers) position.

Table 3. Sound power of omni-directional speaker used in both experiments (Omni.SO8).

\begin{tabular}{lllll}
\hline Frequency $(\mathrm{Hz})$ & 250 & 500 & 1000 & 2000 \\
\hline Sound power $(\mathrm{dB})$ & 69.6 & 74.8 & 71.8 & 63.8 \\
\hline
\end{tabular}

All simulation results were compared to their acoustical parameters of reverberation time (RT) and speech transmission index (STI) [33] with no dome room model as listed in Table 4. All analyses have been evaluated until $2000 \mathrm{~Hz}$ due to 
acoustical parameter design goals which mid-frequency sounds (from $500 \mathrm{~Hz}$ to $2000 \mathrm{~Hz}$ ) included the frequencies that were most important for speech activities, usually happening in mosques.

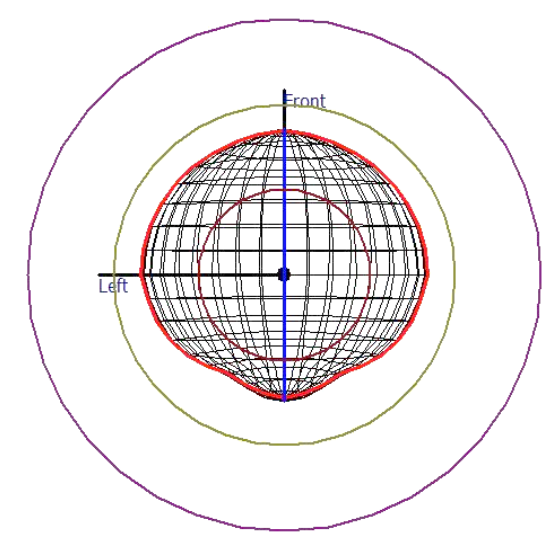

Figure 2. Directional sound source used in this study.

Table 4: Acoustical parameters adopted in this study [33].

\begin{tabular}{lcc}
\hline Acoustical Parameter & Optimum Limits & $\begin{array}{c}\text { Just Noticeable } \\
\text { Difference (JND) }\end{array}$ \\
\hline $\begin{array}{l}\text { Reverberation Time } \\
\text { (T30 average of 500HZ and 1kHz) }\end{array}$ & $1.8 \mathrm{~s}-2.2 \mathrm{~s}$ & $\% 5(0.1 \mathrm{~s})$ \\
\hline $\begin{array}{l}\text { Speech Transmission Index } \\
\text { (STI for single source) }\end{array}$ & $>0.5$ & 0.05 \\
\hline
\end{tabular}

\section{RESULTS AND DISCUSSION}

\section{Reverberation Time (RT)}

Figure 3 shows the comparison of RT in various dome shapes. Similar tendency can be found in all simulation results where the RT values decreased as the frequency increased. This is an expected outcome because the materials used in this study have low absorptive characteristics at low frequencies and the resulting RT is shorter at higher frequencies and become longer at lower frequency regions.

In a lower frequency of $250 \mathrm{~Hz}$, the Arabic shape exhibited the highest value of RT which was $4.11 \mathrm{~s}$ while segmental shape showed the lowest RT of $3.33 \mathrm{~s}$. Based on optimum limits at frequency of $500 \mathrm{~Hz}$ as suggested by Orfali [33], only room models without a dome represented the acceptable agreement. However, nearly all simulated RTs in various dome shapes (except without dome) achieved the optimum limits at frequency of $1000 \mathrm{~Hz}$.

The case of higher deviation of RT values between the segmental dome and Arabic dome, there can be complementary aspects that can explain this phenomenon: (i) the volume of the room model; (ii) the shape and size of surfaces of the dome. The volume of the segmental dome was $5748 \mathrm{~m}^{3}$ while $6616.60 \mathrm{~m}^{3}$ for the Arabic dome. Room model with the Arabic dome was about $15 \%$ larger in volume compared to the room model with a segmental dome. As explained in the basic theory formula of reverberation time, $\mathrm{T}=$ 
$0.161 \mathrm{~V} / \mathrm{A}$, the room volume, $\mathrm{V}$ and the equivalent absorption surface or area, A showed that if the equivalent absorption surface (A) were to maintain in value but the room volume (V) increased, then the RT value will increase. However, the opposite argument can be found if comparison to be made between room model of the Arabic dome and room model of the onion dome, where RT for the onion shape is slightly lower than the Arabic shape even though the room model of onion dome is larger about 5\% in volume than the room model of the Arabic. This phenomenon may be due to the onion dome having more absorption surfaces or areas compared to the Arabic dome. It can be observed that there is a visible deviation in RT between various dome shapes especially below than $1000 \mathrm{~Hz}$. Consequently, it can be concluded that the shape of the dome does affect the reverberation time.

Figure 4 (a) to (d) present the comparison of RT in three locations of dome for each type of dome shapes. Nevertheless, there is less significant improvement by changing the location of the dome. As such, it can be concluded that the dome positions in this study have less significant effect on the RT except segmental dome types at lower than $500 \mathrm{~Hz}$.

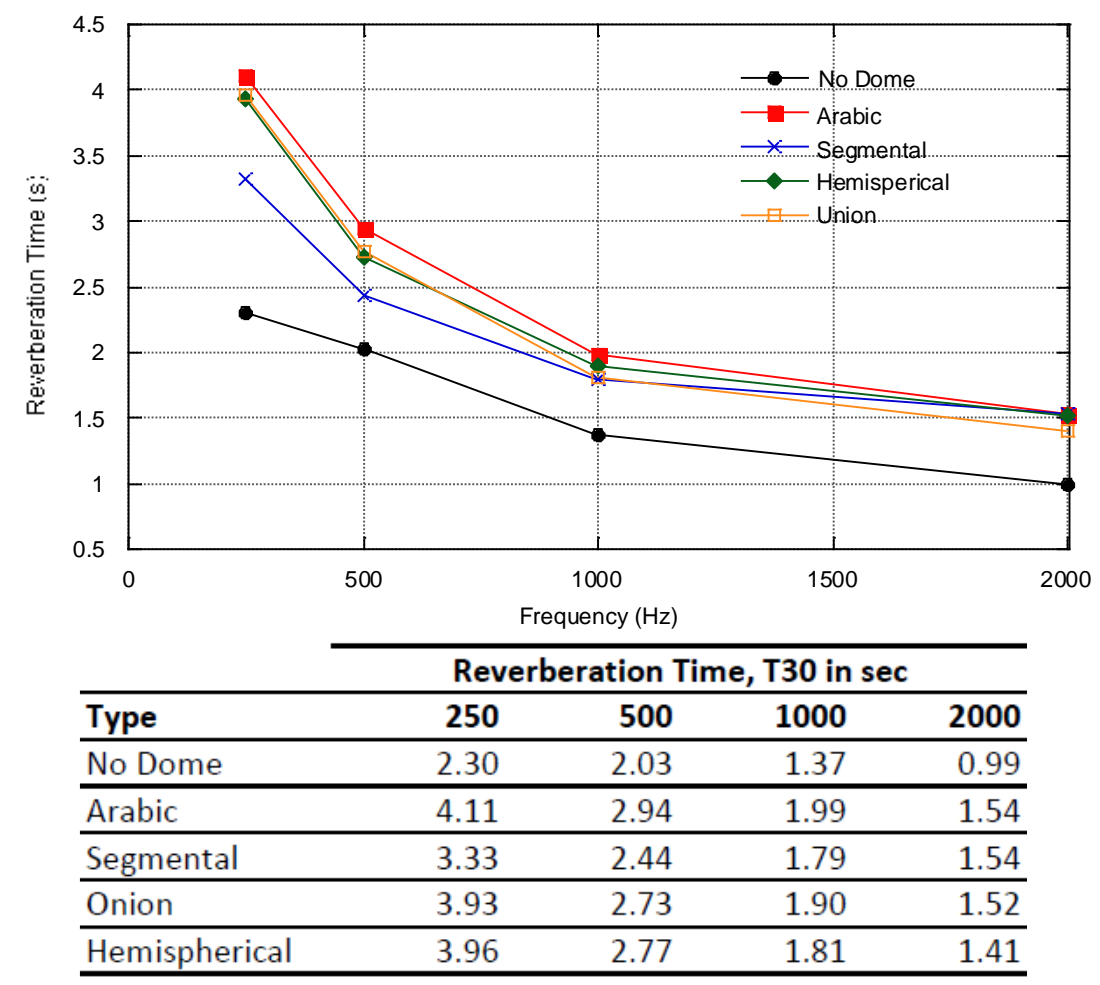

Figure 3: Comparison of reverberation time between various dome shapes.

\section{Speech Transmission Index (STI)}

A mosque typically performs activities involving a lot of speeches whether it is just having a small conversation or giving a talk in front of a crowd, clarity in the speeches is important. Intelligibility is the quality or condition of being understood, which means that speech intelligibility is the value of how clear the speech is in any condition, but should not be confused with speech quality [34-35]. Since reverberation time and sound reflection can affect speech intelligibility, this means that the type of the room, the room shape and volume can also affect speech intelligibility. To achieve a 'good' speech 
intelligibility, the STI value must be within the value of 0.6 to 0.75 ; for a 'fair' speech intelligibility, the STI value must be within the value of 0.45 to 0.6 ; if the STI value were to be below 0.45 than it is considered 'poor'.

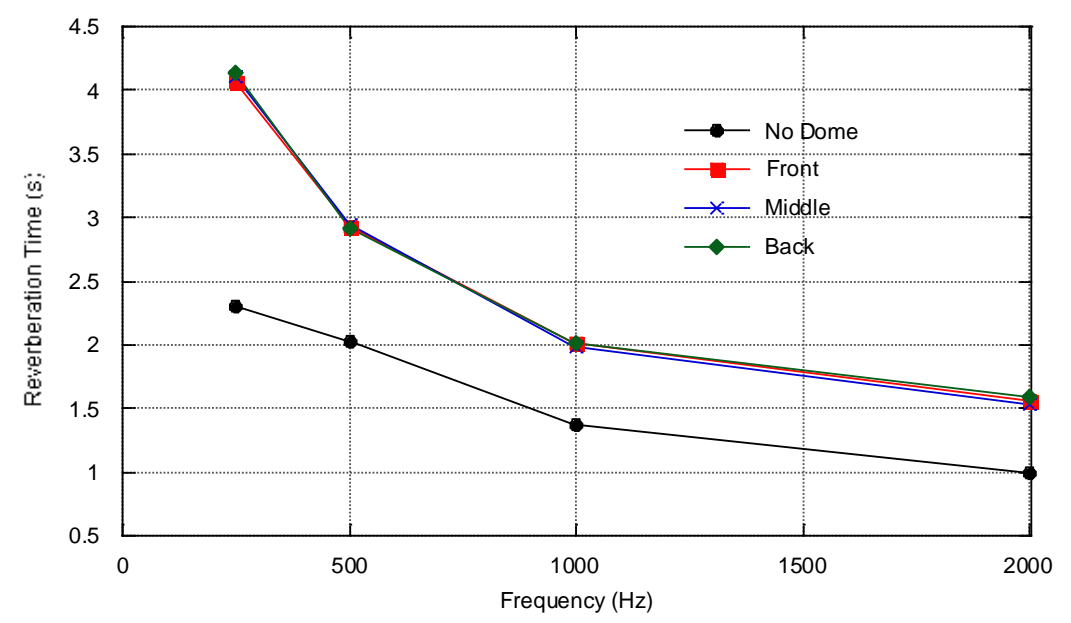

(a)

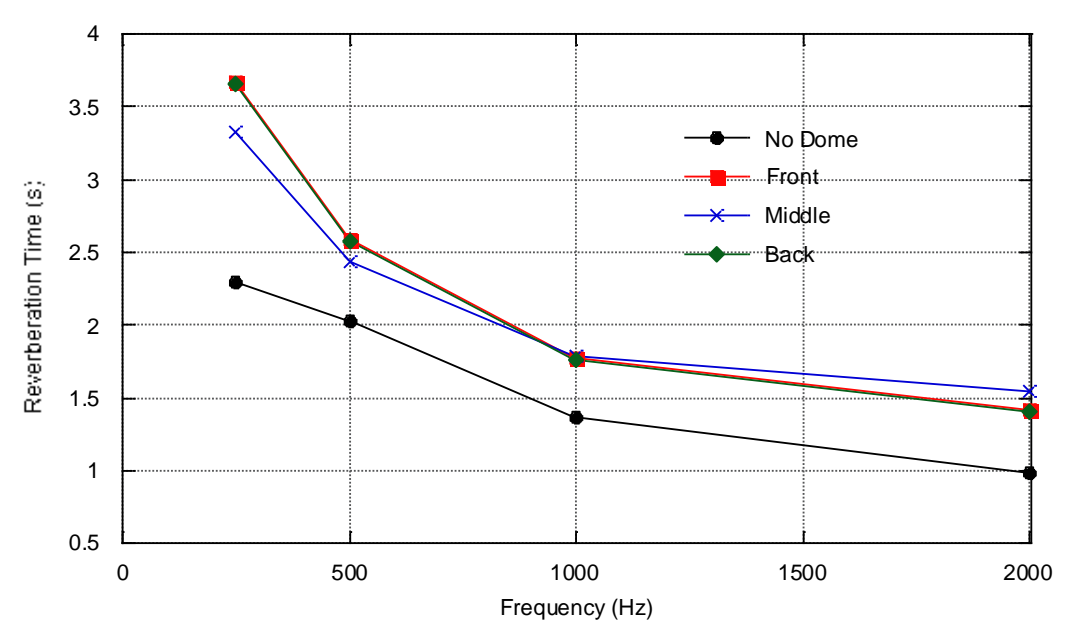

(b)

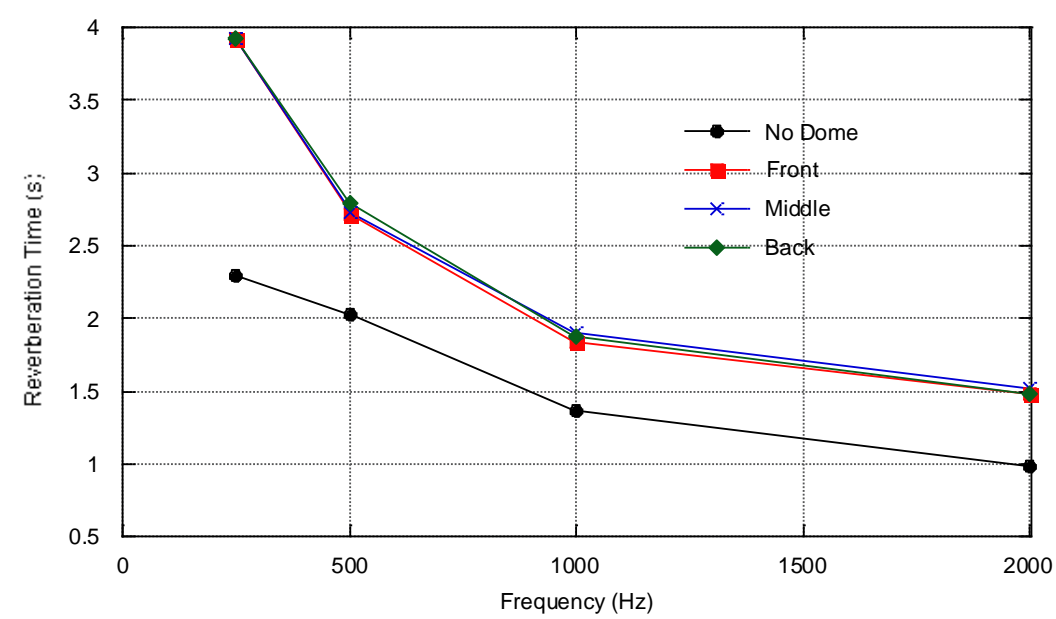

(c) 


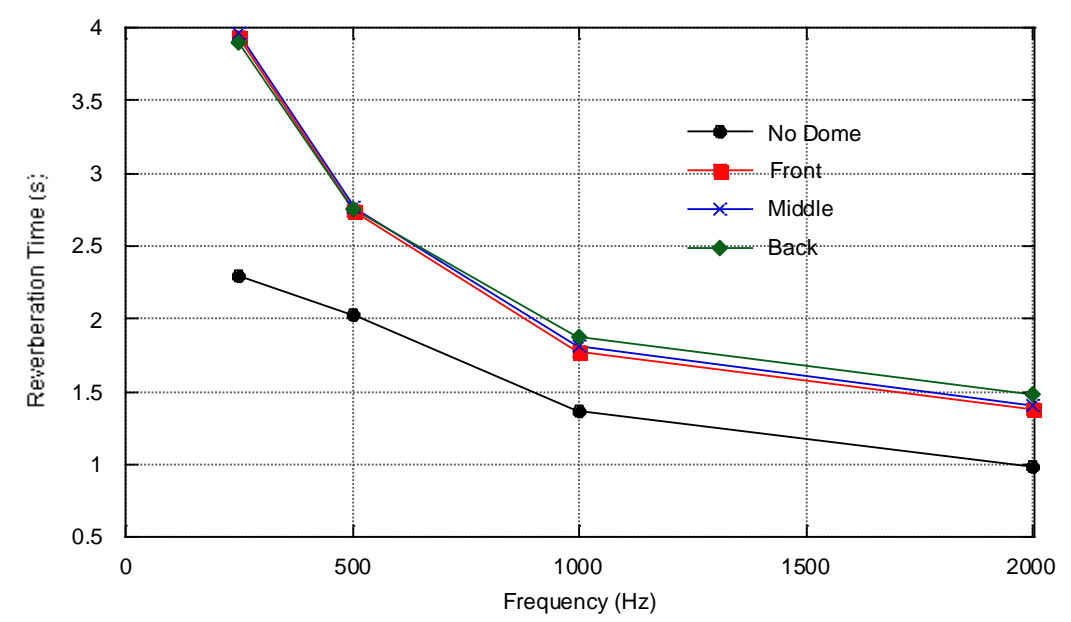

(d)

Figure 4: Comparison of reverberation time between various dome locations; (a) arabic (b) segmental (c) hemispherical (d) onion.

Table 5 shows the comparison of STI values in various dome shapes with their colour contours of STI distribution. It can be observed that simulated models without a dome and those with a segmental dome have the highest average STI value of 0.56 . However, all simulated models showed acceptable values based on the optimum limits adopted in this study even though the lowest STI averaged value found was 0.50 in the Arabic dome. The minimum STI value found in this study can be observed in the simulated model of the Arabic dome type. In general, all dome types including those without a dome have achieved a 'fair' performance of STI values within $5 \mathrm{~m}$ range from the sound source, but the STI values gradually dropped to 'poor' performance when the distance between the sound source and the receiver exceeded approximately $15 \mathrm{~m}$.

Table 5. Comparison of minimum, maximum and average speech transmission index with grid responses for each room model.

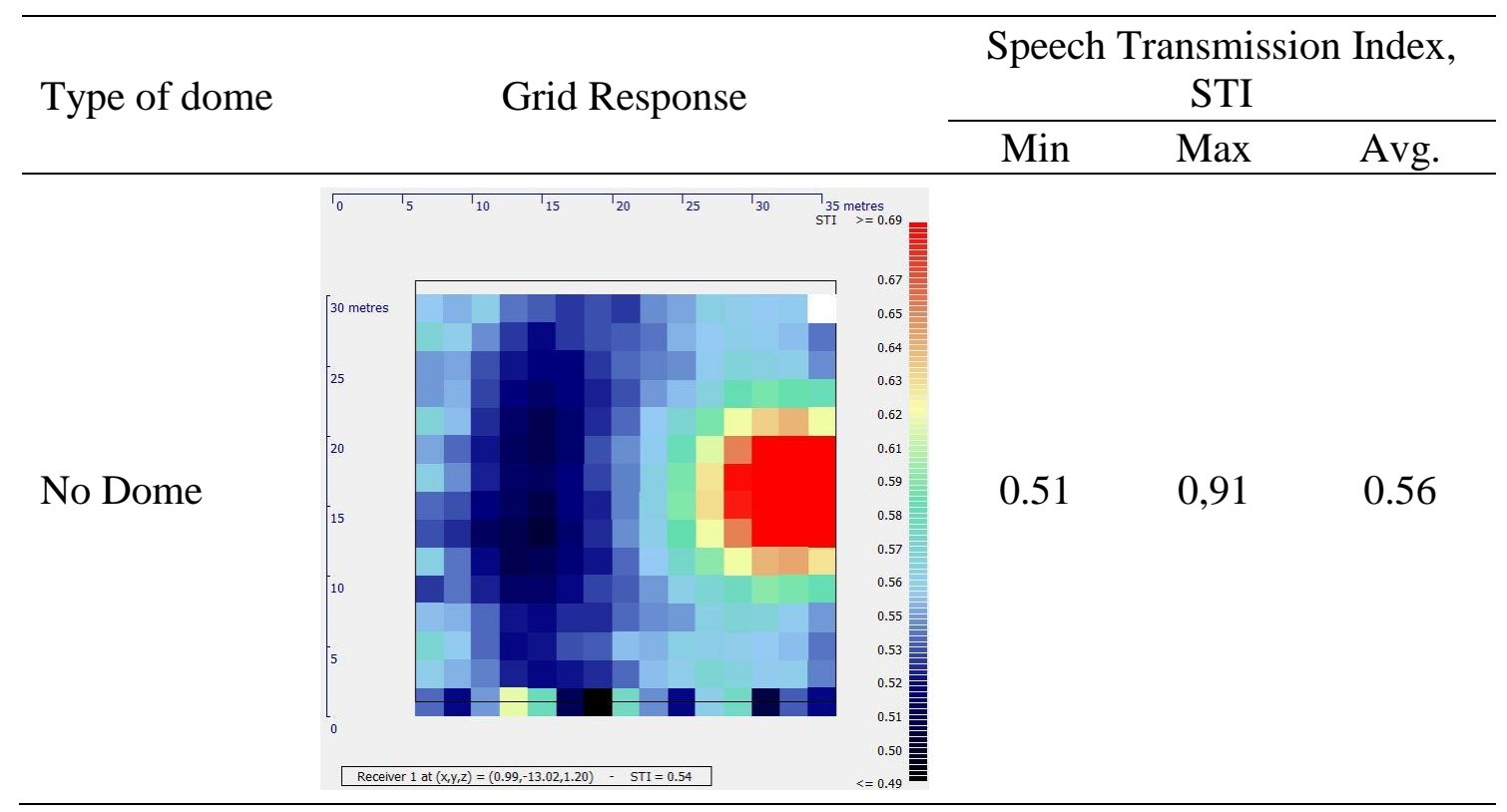




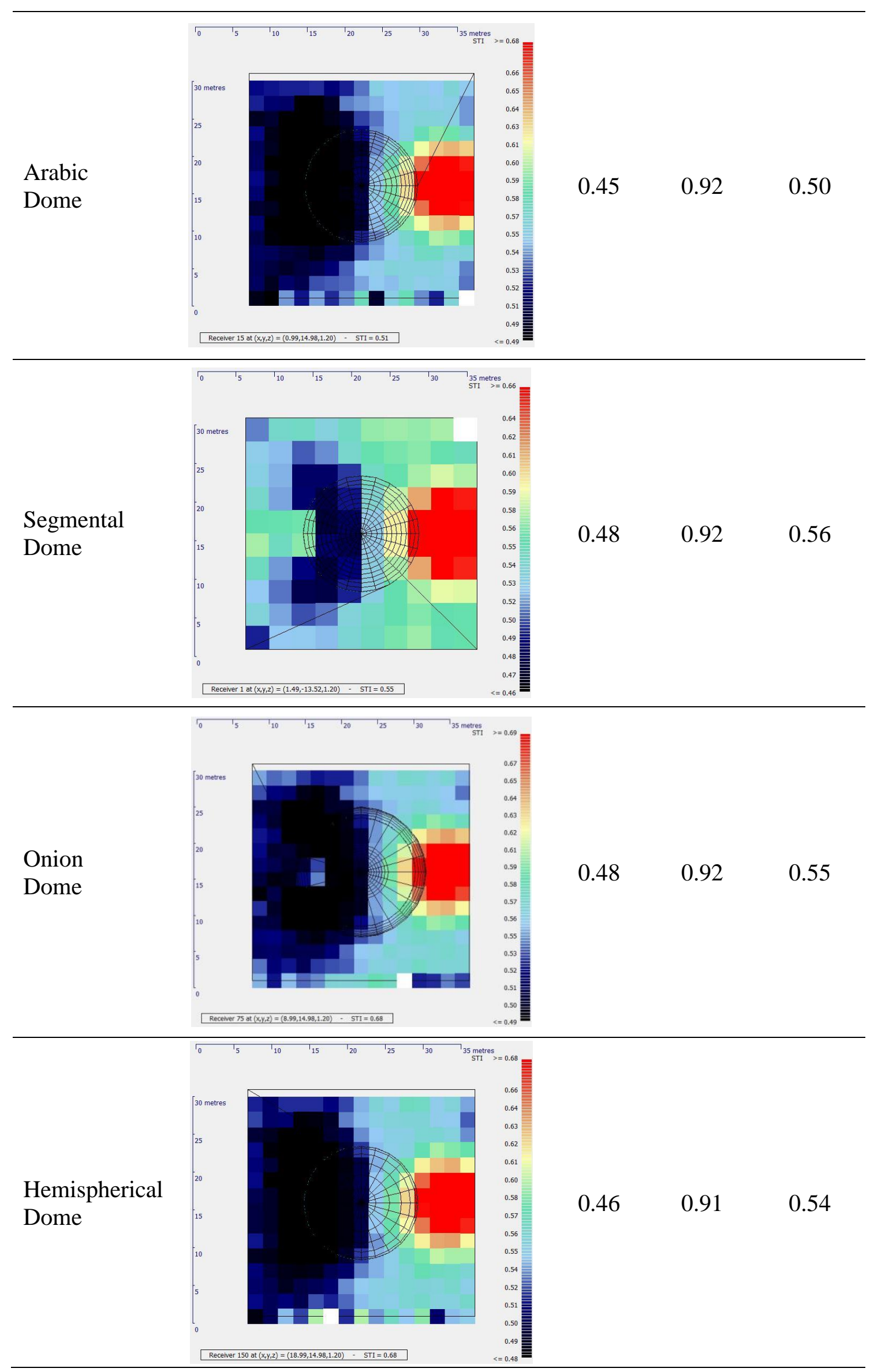


Based on the simulation, the shapes of dome affected the STI mean value as such - the larger the volume, the lower the STI mean value. Taking into consideration the differences in the intensity of the color contour in the grid response, the certainty of the pattern on the grid response of the onion dome and segmental dome are nearly identical. The moment sound is transmited through the respective dome shape, the sound was splitscattered by the sound reflection of the dome shape.

Table 6 presents the comparison of simulated STI values in three locations of dome for each type of dome shapes. The highest averaged STI value recorded for all dome shapes was located at the back with 0.56 . Generally, the result shows that the positioning of any shape of dome somehow can improve the STI when the dome is located at the back, compared to if it were in the middle or front positions. Even though the simulated STI values recorded show comparatively little substantial improvement, it can be concluded that changing the dome location contributes to some improvements in the STI values.

Table 6. Comparison of speech transmission index with respect to dome location.

\begin{tabular}{ccccccccccc}
\hline & \multicolumn{9}{c}{$\begin{array}{c}\text { Speech Transmission Index, STI } \\
\text { Dome Location } \\
\text { Middle } \\
\text { Dome Type }\end{array}$} & \multicolumn{3}{c}{$\begin{array}{c}\text { Front } \\
\text { Min }\end{array}$} & Max & Avg. & Min & Max & Avg. & Min & Max & Avg. \\
\hline Arabic & 0.44 & 0.91 & 0.51 & 0.45 & 0.92 & 0.50 & 0.50 & 0.92 & 0.56 \\
Segmental & 0.47 & 0.91 & 0.54 & 0.48 & 0.92 & 0.56 & 0.48 & 0.92 & 0.56 \\
Onion & 0.45 & 0.93 & 0.53 & 0.48 & 0.92 & 0.55 & 0.50 & 0.92 & 0.56 \\
Hemispherical & 0.45 & 0.90 & 0.51 & 0.46 & 0.91 & 0.54 & 0.48 & 0.92 & 0.56 \\
\hline
\end{tabular}

\section{CONCLUSION}

In this study, a series of simulations have been performed with different shapes and their respective locations of mosque domes on the acoustical performance of reverberation time and speech transmission index by means of computer simulations. From the results obtained, it can be concluded that dome shape can affect reverberation time especially in low frequency regions. However, there is less significant changes in reverberation time that could be observed in the results when different locations of the dome were being simulated in this study. Meanwhile, the dome shape would affect speech transmission index adversely - the larger the volume is, the lower the STI becomes. However, it should be noted that while all models were simulated with fixed materials and similar size of prayer hall dimension, the positioning of the dome can also improve the speech transmission index value. Further investigations and analysis on other acoustical parameters are now being pursued intensively.

\section{ACKNOWLEDGEMENT}

The authors would like to gratefully acknowledge the financial support under Fundamental Research Grant Scheme project FP030-2014B. 


\section{REFERENCES}

[1] Ikhwanuddin R, Utami SS. Analisis Pengaruh Geometri Kubah Terhadap Kondisi Akustik Masjid Ar Fachruddin Umm Menggunakan Catt-Acoustic. Doctoral dissertation, Universitas Gadjah Mada; 2014

[2] Othman AR, Harith CM, Ibrahim N, Ahmad SS. The Importance of Acoustic Design in the Mosques towards the Worshipers' Comfort. Procedia-Social and Behavioral Sciences. 2016; 234: 45-54.

[3] Jaafar ZB, Madzalan JB, Ariffin SB. Al-Quran Teaching and Learning by AlQabisi Model: A Study Towards Excellent Students Ulul Albab Tahfiz Model and Tahfiz Stifin. Advanced Science Letters. 2018; 24(1):169-71.

[4] Calis G, Alt B, Kuru M. Thermal Comfort and Occupant Satisfaction of a Mosque in a Hot and Humid Climate. In Computing in Civil Engineering. pp. 139-147; 2015.

[5] Nazli CD, Adzahan Z, Razak AS, Abdullah Z, Jusoh MZ, Dimon MN. Comparison of the acoustical performance of mihrab design in mosques using computer simulation studies. In INTER-NOISE and NOISE-CON Congress and Conference Proceedings, Institute of Noise Control Engineering. pp. 2387-2396; 2015.

[6] Macaulay D. Mosque. Houghton Mifflin Harcourt; 2008 Apr 28.

[7] Khan H. Contemporary Mosque Architecture. ISIM Review. 2008; 21: 2.

[8] Hong T, Chou SK, Bong TY. Building simulation: an overview of developments and information sources. Building and Environment 2000; 35:347-61.

[9] Hensen JLM, Lamberts R. Building Performance Simulation for Design and Operation. London: Spon Press; 2001.

[10] Hensen JLM. Towards more effective use of building performance simulation in design. In: Leeuwen JP van, Timmermans HJP (Eds.) Proc 7th Int Conf Des Decis Support Syst Archit Urban Plan, Eindhoven; 2004.

[11] Augenbroe G. Trends in building simulation. In Malkawi A, Augenbroe G, editors. Advanced building simulation, London: Taylor \& Francis, 2004, p 18-38.

[12] Siltanen S, Lokki T, Savioja L, Lynge Christensen C. Geometry reduction in room acoustics modeling. Acta Acustica united with Acustica. 2008; 94(3): 410-8.

[13] Rindel JH, Christensen CL. Odeon, a design tool for noise control in indoor environments. In: Solutions for Managing Occupational Noise Risk: Noise at work, Lille, France, pp. 1-9; 2007.

[14] Rindel JH. Room Acoustic Prediction Modelling. In: XXIII Encontro da Soc Bras Acústica, Salvador, Brazil; 2010.

[15] Vorländer M. Review Papers - Virtual Acoustics, Archives of Acoustics, 2014; 39(3): 307-18.

[16] M. Hornikx, Acoustic modelling for indoor and outdoor spaces, Journal of Building Performance Simulation, 2015; 8(1), 1-2.

[17] Koutamanis A. Digital architecture visualization. Automation in Construction, 2000;9:347-60.

[18] Yin X, Wonka P, Razdan A. Generating 3D Building Models from Architectural Drawings: A Survey. IEEE Computer Graphics and Applications, 2009; 29: 2030.

[19] Poirier L. Devious Design: Digital Infrastructure Challenges for Experimental Ethnography. Design Issues. 2017; 33(2): 70-83. 
[20] Nazli, CD, Adzahan Z, Abdullah Z, Harun M, Dimon MN. Acoustical performance of mosques: An overview of current research in Malaysia. In ICSV24 Conference Proceedings, International Institute of Sound \& Vibration. pp. 4091-4097; 2017.

[21] Ahmad, Y., Nazli, C. D., \& Othman, R. Mihrab design and its basic acoustical characteristics of traditional vernacular mosques in Malaysia. Journal of Building Performance, 2013; 4(1):44-51.

[22] Ardhiati Y. The new architecture of mosque design to express the modernity of moslems. Global Advanced Research Journal of Arts and Humanities (GARJAH). 2013; 2(4):75-8.

[23] Kayili M. Acoustic solutions in classic ottoman architecture. Manchester: Aasiya Alla FSTC Limited; 2005.

[24] Rayleigh JW. Scientific papers: six volumes bound as three, Dover, pp.19021910; 1964.

[25] Sabine WC. Collected Papers on Acoustic. London: Harvard University Press; 1922.

[26] Topaktaş İL. Acoustical properties of classsical Ottoman mosques simulation and measurement (Doctoral dissertation, METU); 2003.

[27] Sü Gül Z, Çalışkan M. Acoustical Design of Turkish Religious Affairs Mosque. The Journal of the Acoustical Society of America. 2013;133(5):3404.

[28] Ben-Yosef D. Soundings in the Fortification. In A. Zertal (Ed.), El - Ahwat, A fortified Site from the Early Iron Age Near Nahal 'Iron, Israel, 2012; pp. 163.

[29] Dodge H. Building Material and Techniques in the Eastern Mediterranean from the Hellenistic Period to the Fourth Century AD. 1984. University of Newcastle.

[30] Hassan, AS, Mazloomi M. The Importance of Plan Unit Design with Reference to Pedentive Dome Mosque Architecture in Early Ottoman Period in Balkan Region and Anatolia. Review of European Studies, 2010; 2(2), 105.

[31] Huerta S. Oval domes: History, geometry and mechanics. Nexus Network Journal. 2007; 9(2):211-48.

[32] Cristensen CL, Koutsouris G. Odeon Room Acoustics Software Version 13. Full User's Manual. Lyngby, DK: Odeon A/S, Schion DTU. 2015.

[33] Orfali WA, Ahnert W. Measurements and verification of two mosques in Saudi Arabia. The Journal of the Acoustical Society of America. 2006; 119(5):3208.

[34] Steeneken HJ. The measurement of speech intelligibility. Proceedings-Institute of Acoustics. 2001; 23(8):69-76.

[35] Schwerin B, Paliwal K. An improved speech transmission index for intelligibility prediction. Speech Communication. 2014; 65:9-19. 